\section{4 \\ A NOTE ON SOCIO-ECONOMIC DEVELOPMENT IN MALUKU}

\author{
Budy P. Resosudarmo
}

History tells us that the Maluku (or Moluccan) islands were famous for their spice products, and so were named the Spice Islands. As the dominance of these islands in the spice trade came to an end, the local economy began to decline. Data from the early 1980s show that Maluku was one of the poorest and most poverty-stricken regions in Indonesia. The violence that broke out in 1999 set the province back even further: thousands of people died, tens of thousands became refugees, and houses and other infrastructure were destroyed. The conflict continued more or less uninterrupted until 2003, although by most accounts 2001 was a slightly more peaceful year than 2000. In the northern part of Maluku, the violence had pretty much tapered off by $2001 .{ }^{1}$

The province of Maluku was formally established in 1957 by Emergency Law No. 22/1957 (replaced in 1958 by Law No. 20/1958). Maluku is made up of over 1,000 islands (Map 4.1) The provincial capital is Ambon, located on the island of Ambon. The three largest islands are Halmahera, Seram and Buru. The province covers a territory of approximately 850,000 square kilometres, making it one of the largest provinces in Indonesia. However, more than 90 per cent of it is ocean, and the total land area is only $75,000-85,000$ square kilometres. ${ }^{2}$ The distance from the northernmost to the southernmost part of Maluku is nearly 1,000 kilo
Map 4.1 Maluku

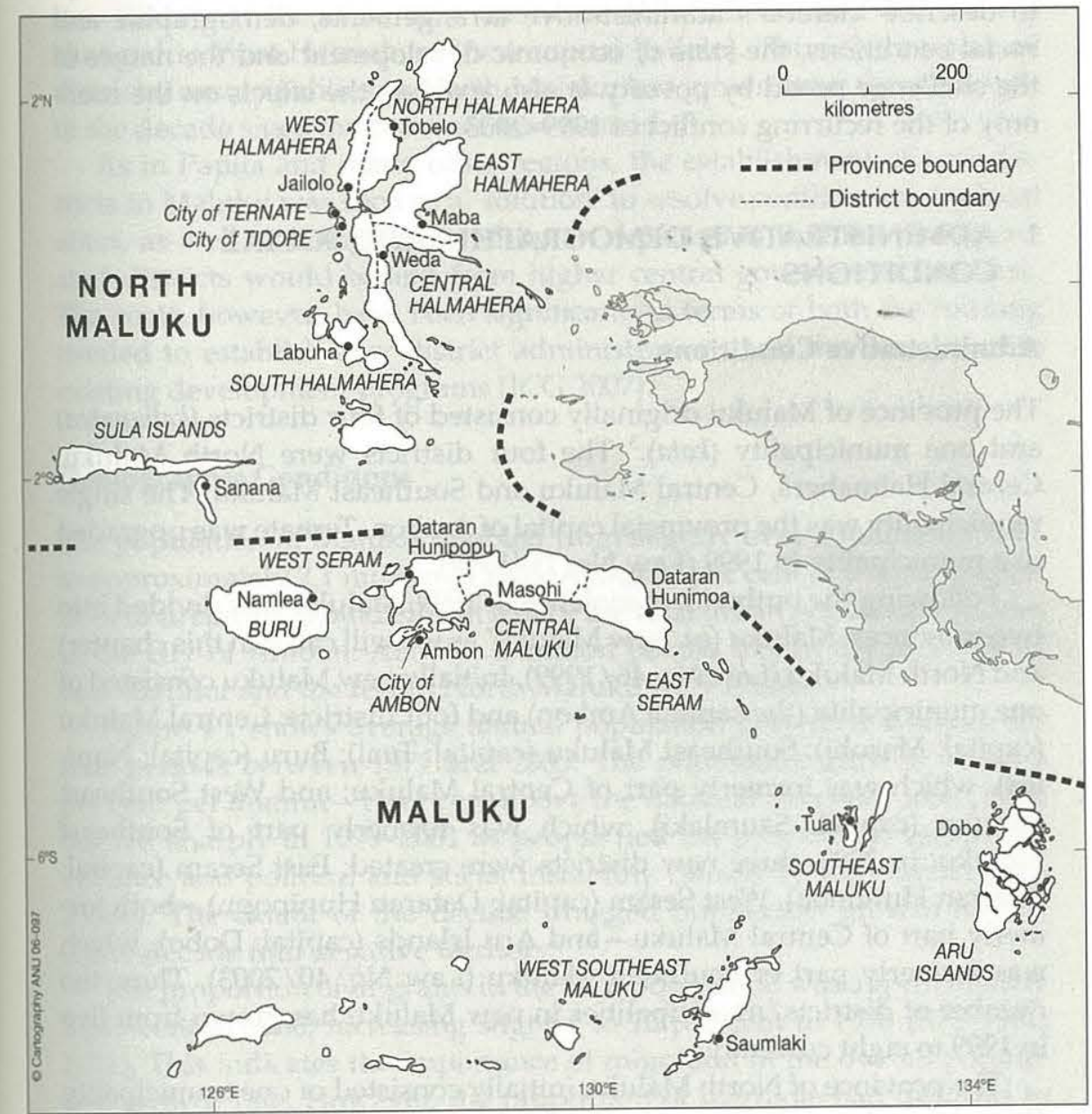

1 See van Klinken (2001), Brown, Wilson and Hadi (2003), Duncan (2005a) and Pariela (2007), as well as Chapter 12 by Thorburn, for a detailed discussion of the conflict and its consequences.

2 These figures are for Maluku before it was divided into two provinces in 1999. 
metres, equal to the distance from Jakarta to Medan. These geographical conditions pose a serious challenge to attempts to develop the region (Meyer and Hardjodimedjo 1989; Monk, de Fretes and ReksodiharjoLilley 1997; Brown, Wilson and Hadi 2003).

Maluku is urgently in need of well-considered development policies underpinned by a thorough understanding of current socio-economic trends. Although reliable data are hard to obtain, this chapter will attempt to describe Maluku's administrative arrangements, demographic and social conditions, the state of economic development and the nature of the challenge posed by poverty. It also analyses the effects on the economy of the recurring conflict of 1999-2003.

\section{ADMINISTRATIVE, DEMOGRAPHIC AND SOCIAL CONDITIONS}

\section{Administrative Conditions}

The province of Maluku originally consisted of four districts (kabupaten) and one municipality $(k o t a) .^{3}$ The four districts were North Maluku, Central Halmahera, Central Maluku and Southeast Maluku. The single municipality was the provincial capital of Ambon. Ternate was upgraded to a municipality in 1999 (Law No. 11/1999).

Following the outbreak of violence in 1999, Maluku was divided into two provinces: Maluku (or 'new Maluku' as we will call it in this chapter) and North Maluku (Law No. 46/1999). Initially new Maluku consisted of one municipality (the capital, Ambon) and four districts: Central Maluku (capital: Masohi); Southeast Maluku (capital: Tual); Buru (capital: Namlea), which was formerly part of Central Maluku; and West Southeast Maluku (capital: Saumlaki), which was formerly part of Southeast Maluku. In 2003, three new districts were created: East Seram (capital: Dataran Hunimoa), West Seram (capital: Dataran Hunipopu) - both formerly part of Central Maluku - and Aru Islands (capital: Dobo), which was formerly part of Southeast Maluku (Law No. 40/2003). Thus, the number of districts/municipalities in new Maluku has grown from five in 1999 to eight currently.

The province of North Maluku initially consisted of one municipality (Ternate) and two districts: North Maluku (capital: Ternate) and Central Halmahera (capital: Tidore). The capital of the province is Sofifi on the

3 Provincial governments are the highest level of regional government in Indonesia. Districts (kabupaten) and municipalities (kota) comprise the second highest level. Below them are the subdistricts (kecamatan) and villages (kelurahan or desa). island of Halmahera. While infrastructure is being built in Sofifi, Ternate is functioning as the provincial capital. In 2003, one new municipality (Tidore) and four new districts were formed in this province (Law No. 1/2003). The new districts were North Halmahera (capital: Tobelo), South Halmahera (capital: Labuha), Sula Islands (capital: Sanana) - all originally part of North Maluku district-and East Halmahera (capital: Maba), which was hived off from Central Halmahera district (new capital: Weda). At the same time the name of North Maluku district was changed to West Halmahera (new capital: Jailolo). Thus, the number of districts/municipalities in North Maluku has grown from three to eight in the decade since the province was formed.

As in Papua and many other regions, the establishment of new districts in Maluku was seen as a 'solution' to resolve conflicts among local elites, as well as being triggered by an expectation that the newly created districts would benefit from higher central government transfers. The costs, however, have been significant, in terms of both the funding needed to establish new district administrations and the disruption to existing development programs (ICG 2007).

\section{Demographic Conditions}

The population of Maluku doubled from slightly over 1 million in 1971 to approximately 2.1 million in 2005 . About 27 per cent of the population lives in urban areas, and almost half of the total urban population resides in the city of Ambon. About 1.2 million people live in the province of new Maluku and the rest in North Maluku (BPS 2006b).

Figure 4.1 shows average annual population growth in Maluku for four periods between 1971 and 2005. The population grew at about 3 per cent per annum - 1 per cent above the national average - until 1998, but fell sharply in 1999-2001 as people fled the province to escape the violence and political and social instability caused by the conflict (BPS 2006b). The extent of the decline dragged population growth for the entire decade into negative territory.

The proportion of migrants in the total population was approximately 9 per cent in 1980, increasing slightly to 10 per cent in 1990 (BPS 1981, 1991). This indicates the importance of migration in the overall population growth rate. However, the proportion of migrants had declined to 6 per cent by 2005, from around 187,000 migrants in 1990 to 137,000 in 2005. The conflict wracking the province undoubtedly contributed to this decline: most of those who left Maluku were migrants, many of them returning to nearby parts of Sulawesi from whence they had originally come (Duncan 2005b).

In 1990, 85 per cent of migrants in Maluku came from five provinces: Southeast Sulawesi (28 per cent), East Java (23 per cent), Central Java (15 
Figure 4.1 Maluku: Average Annual Population Growth, 1971-2005 (\%)

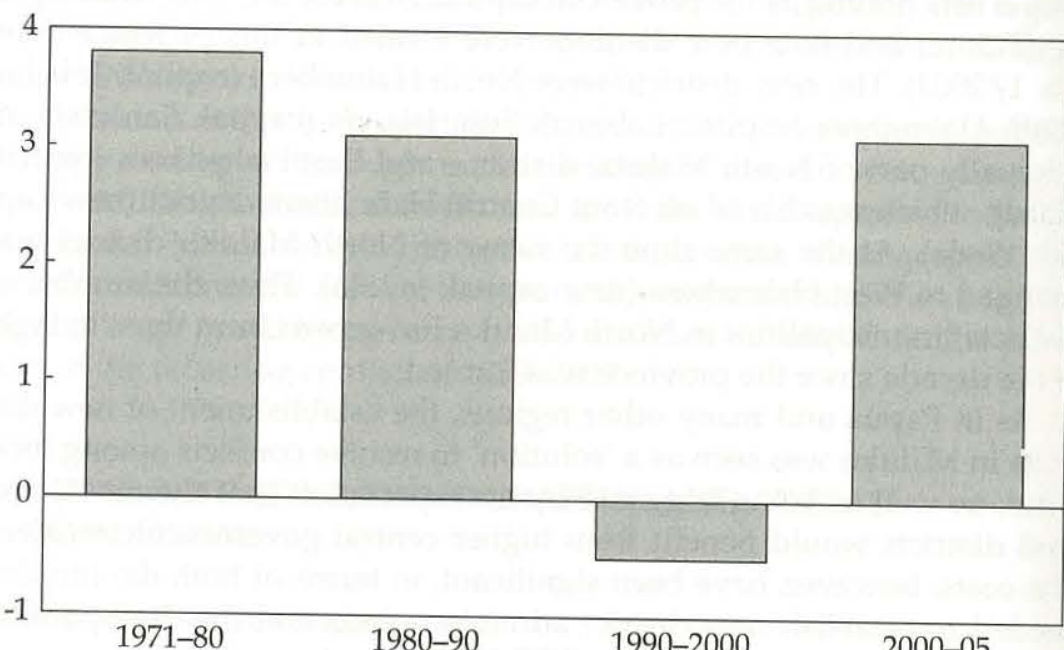

Source: BPS $(1981,1991,2000,2006 a)$.

per cent), South Sulawesi (10 per cent) and North Sulawesi ( 9 per cent). In 2005, these five provinces still accounted for 80 per cent of migrants, but in a slightly different order: East Java (24 per cent), Southeast Sulawesi (17 per cent), Central Java (16 per cent), South Sulawesi (13 per cent) and North Sulawesi (10 per cent). Between 1990 and 2005, the number of migrants from Southeast Sulawesi fell from 51,000 to 21,000; the number from East Java from 43,000 to 30,000; the number from Central Java from 28,000 to 19,000; the number from South Sulawesi from 19,000 to 16,000; and the number from North Sulawesi from 16,000 to 13,000 (BPS 1991, 2006a). Among the migrants who chose to stay in Maluku, 41 per cent were living in urban areas in 2005: 42 per cent in new Maluku and 39 per cent in North Maluku (BPS 2006a).

Data on religion for the whole of Maluku show that in 2005, 58 per cent of the population was Muslim, 37 per cent Protestant, 4 per cent Catholic and 1 per cent other religions. However, there were marked differences between the provinces. In North Maluku, approximately 79 per cent of the population was Muslim, 20 per cent Protestant and 1 per cent Catholic. Most Protestants and Catholics resided in urban areas; their share of the total urban population was 32 per cent in the case of Protestants and 2 per cent in the case of Catholics. But in new Maluku, only 44 per cent of the population was Muslim, while 49 per cent were Protestant, 6 per cent were Catholic and 1 per cent belonged to other religions. Muslims made up 49 per cent of the urban population and Protestants 42 per cent. In rural areas, however, Protestants (58 per cent) significantly outnumbered Muslims (38 per cent).
Most migrants are Muslim. But if we recall that migrants comprise only 6 per cent of the Maluku population - not enough to skew the data strongly in their favour - the religious composition of the two provinces just described would seem to be a fair representation of the religious composition of the indigenous population of Maluku.

\section{Social Conditions}

Social indicators for Maluku improved slowly until 1999, then slid backwards. However, they have never been as bad as in some other regions, notably East and West Nusa Tenggara, West Kalimantan, Southeast Sulawesi and Papua. Maluku's score on the human development index (HDI) rose from 64.1 in 1990 to 67.2 in 1999 before falling back to 66.2 in 2002. In all three years its score was above the national average, of 63.4 in 1990, 64.3 in 1999 and 65.8 in 2002. In terms of its ranking among Indonesia's 26 provinces, Maluku advanced from thirteenth position in 1990 to fifth position in 1999, then fell back to thirteenth position in 2002 (BPS, Bappenas and UNDP 2001, 2004). ${ }^{4}$ The main factor in these relatively good results was the outperformance of its education sector.

\section{Education}

Together with North Sumatra, West Sumatra and North Sulawesi, Maluku is one of the few regions outside Java to have had a relatively well-developed education sector since the Dutch colonial era (Meyer and Hardjodimedjo 1989). Its performance in education, particularly basic education, has been significantly above the national average for several decades.

In 1990, Maluku's adult literacy rate (literacy among those aged 15 and over) was 91.4 per cent and educational attainment among adults (measured by years of schooling) was 5.9 years. These were good results by Indonesian standards - better than those for West Java, for example. By 1999, the adult literacy rate had risen to 95.8 per cent (compared with a national average of 88.4 per cent) and educational attainment to 7.6 years (compared with a national average of 6.7 years). Among Indonesia's 26 provinces, Maluku ranked fourth in terms of literacy and sixth in terms of educational attainment in 1999. Even after the violence broke out, Maluku continued to notch up some of the best educational outcomes in the country: the adult literacy rate was 96.3 per cent in new Maluku and 95.6 per cent in North Maluku in 2002, while educational

4 Figures for the provinces of new Maluku and North Maluku have been aggregated to allow for comparisons between the pre- and post-1999 data. 
attainment was 8.0 years in the former province and 8.4 years in the latter province. Moreover, adult literacy and educational attainment did not vary much across districts, with the usual exception of above-average figures for the capital, Ambon. Across islands within a district, however, variations in adult literacy and educational attainment are suspected to be relatively high. Most schools are located on the bigger islands, out of reach of the children living on smaller islands where transport links are poor (BPS 1996; BPS, Bappenas and UNDP 2004).

In higher education as well, Maluku has performed reasonably well. For example, in 2002, 22 per cent of adults aged 15 and over had at leas a high school degree (compared with a national average of 20 per cent) and 1.9 per cent had a tertiary degree (compared with a national average of 2.2 per cent) (BPS 2006a)

\section{Employment}

The Maluku workforce grew at an average annual rate of 2.2 per cent between 1980 and 1999, faster than the national average of 1.8 per cent, before slowing to 1.3 per cent in 2000-02. The total workforce increased from approximately 597,000 people in 1980 to $1,514,000$ people in 2002 92 per cent of them working and the rest either unemployed or looking for work. The main source of employment was agriculture (including forestry and fisheries), which soaked up about 57 per cent of the workforce in 2002. This was followed by community, social and personal services (12 per cent) and trade, hotels and restaurants (12 per cent). The composition of the workforce differed between new Maluku and North Maluku In new Maluku, around 66 per cent of the workforce was employed in the agricultural sector, 11 per cent in community, social and personal services, and 8 per cent in trade, hotels and restaurants. The figures for North Maluku were 42 per cent, 15 per cent and 18 per cent respectively (BPS 2003; BPS, Bappenas and UNDP 2004).

\section{Health}

Maluku has performed below the national average on health indicators In 1996 life expectancy was 63.1 years, a little below the national average of 64.4 years. In 2002, life expectancy was 65.5 years in new Maluku and 63.0 years in North Maluku, compared with 66.2 years for the nation as a whole. The infant mortality rate in new Maluku and North Maluku combined was 66 deaths per 1,000 live births in 2000, well above the national figure of 47.5

5 There are no infant mortality data for the individual provinces as yet.
Maluku's relatively poor performance in health can be attributed to its lack of health infrastructure. In 2002, 26.1 per cent of the population of new Maluku and 42.2 per cent of the population of North Maluku had no ready access to a health care facility, compared with 23.1 per cent for Indonesia as a whole (BPS, Bappenas and UNDP 2004). Fixing this deficit clearly requires urgent attention.

\section{THE ECONOMY}

\section{Growth}

Since its dominance of the spice trade ended, Maluku has struggled to find other sectors to compensate. The agricultural sector, particularly forestry and fisheries, continues to play a major part in the economy, but its performance has not been impressive. Between 1975 and 1996, for example, the sector grew at only 3 per cent per annum, below the national figure of 4 per cent (BPS, various years).

Services, particularly trade services, contributed around 31 per cent of Maluku's gross domestic product (GDP) in 1975. The sector grew at an average annual rate of 13.6 per cent between 1975 and 1983, driving provincial GDP growth of 8.1 per cent (compared with 7.3 per cent for the whole of Indonesia) (BPS, various years). Although the services sector continued to grow at the respectable rate of 6.6 per cent per annum between 1984 and 1996, the main driver of GDP growth during this latter period was industry.

Industry (mining, manufacturing, utilities and construction) was the fastest growing sector between 1975 and 1996; the fastest growing industrial subsectors were the fish-processing, sawmill and plywood industries. $^{6}$ The industrial sector grew at close to 20.5 per cent per annum between 1975 and 1983, but this was from a very low base. Between 1975 and 1983, its share of provincial GDP increased from 5 per cent to 18 per cent. The sector continued to record strong growth of 15.7 per cent per annum between 1984 and 1996. The momentum in the sector during this period pushed Maluku's annual rate of GDP growth to 7.5 per cent, above the national average of 7 per cent (BPS, various years).

Thus, in the mid-1990s Maluku appeared to be making significant progress towards shifting from an agriculture-dominated economy to a more broadly based economy in which industry and services played a larger role. The share of the agricultural sector fell to just 26 per cent in

6 Based on information provided by Mukhtar A. Adam, lecturer, Khairun University, Ternate. 
Figure 4.2 Maluku: Growth in GDP, 1994-2003 (\%)

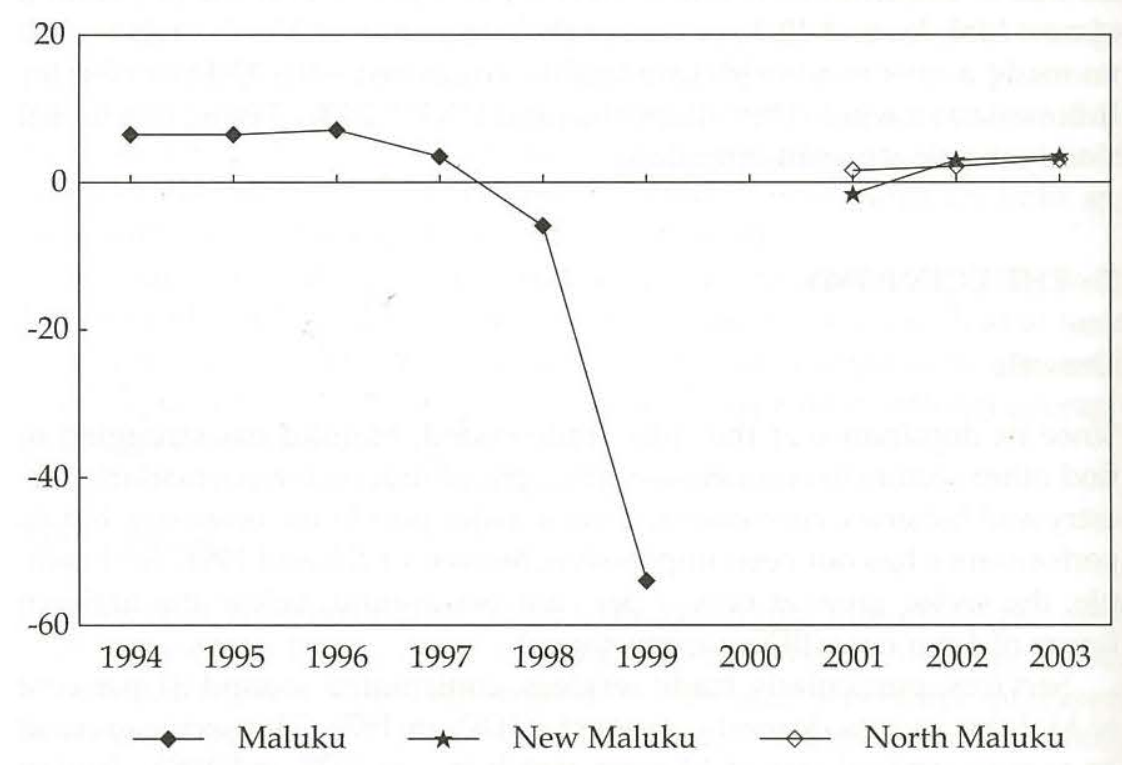

a In 1993 constant prices.

Source: BPS (various years).

1996 - a significant reduction from 63 per cent in 1975 - while the shares of industry and services rose to 32 per cent and 42 per cent respectively (BPS, various years).

The 1997-98 Asian economic crisis and the 1999-2003 conflict in Maluku put an end to this progress. From 7.1 per cent in 1996, annual growth in GDP slowed to 3.5 per cent in 1997 and slid further to -3.5 per cent in 1998, mainly because of the crisis (Figure 4.2). Maluku's industrial sector was the hardest hit; its contribution to GDP halved from 32 per cent in 1996 to just 16 per cent in 1998. At the peak of the conflict in 1999 , the GDP growth rate collapsed to -54 per cent. No other province in Indonesia has ever experienced an economic collapse on this scale - not even Aceh after the 2004 tsunami.

In 2001 (after Maluku was divided into two provinces), North Maluku recorded positive growth in GDP, while new Maluku had to wait another year to enter positive territory (Figure 4.2). Clearly this was because new Maluku (especially Ambon) was the locus of discontent during the extended period of unrest. In 2003, the GDP growth rates of both provinces stood at about 3.5 per cent, still well below the rates recorded before 1997.

\section{Structural Change}

Nearly all sectors were negatively affected by the 1997-98 economic crisis, but the situation was made much worse by the ensuing socio-political conflict. During this period activity fell in every sector. However, because most of the violence occurred in urban areas, industry and services were particularly badly affected. The speed of recovery has varied across sectors, changing the structure of Maluku's economy (Table 4.1). In 2004, the contribution of the industrial sector to provincial GDP was just 13 per cent (less than half its share in 1996), while the contribution of agriculture had increased significantly to 37 per cent.

Construction was the industrial subsector that bore the brunt of the contraction between 1996 and 2004: the economic crisis slowed activity, then the outbreak of conflict brought it to a halt. Because of the widespread damage caused by the unrest, one might have expected this subsector to recover quickly in the post-conflict period. Between 2002 and 2004 , however, growth in the construction subsector was at best moderate. This suggests that the reconstruction effort is making only slow progress. Good infrastructure underpins the health of all sectors of the economy. It is therefore important that the province's damaged infrastructure be fixed as quickly as possible.

Mining was the next worst-hit subsector, as investor confidence plummeted. In addition to the national economic crisis and the unstable local conditions, investors had to cope with the regulatory uncertainties caused by the rapid shift from a centralized to a decentralized system of government in 2001. Signs of improvement can be seen in new Maluku, where growth in mining averaged 3.3 per cent in 2002-04. However, North Maluku may not experience a sustained recovery until BHP Billiton and the Indonesian company Antam are ready to develop the Buli nickel deposit on the island of Halmahera.

Manufacturing also took a pummelling as business confidence nosedived. It recorded growth of only 1.9 per cent in new Maluku and 3.4 per cent in North Maluku in 2002-04. Problems with infrastructure undoubtedly contributed to the subsector's difficulties; the reconstruction of markets, electricity, roads and telecommunications has been slow in many districts.

As one would expect, Maluku's troubles hit capital investment as well as both exports and imports (Table 4.2). As a result, the expenditure side of the economy became dominated by household and government consumption; the former expanded from 41.9 per cent in 1996 to 71.3 per cent in 2004, while the latter increased from 13.5 per cent to 25.0 per cent. After the conflict, capital investment appeared to recover faster in new Maluku than in North Maluku, growing by 11.6 per cent in 2002-04. Most of the expenditure was directed towards replacing old or dam- 
Table 4.1 Maluku: Composition of GDP by Sector, 1996-2004 (\%)

\begin{tabular}{|c|c|c|c|c|c|c|c|c|}
\hline & \multicolumn{4}{|c|}{ Maluku } & \multicolumn{2}{|c|}{ New Maluku } & \multicolumn{2}{|c|}{ North Maluku } \\
\hline & 1996 & 2001 & $2004^{\mathrm{b}}$ & $\begin{array}{l}\text { Growth, } \\
1997-2004\end{array}$ & 2004 & $\begin{array}{l}\text { Growth, } \\
\text { 2002-04 }\end{array}$ & 2004 & $\begin{array}{l}\text { Growth, } \\
\text { 2002-04 }\end{array}$ \\
\hline Agriculture & 25.7 & 36.1 & 36.5 & -0.9 & 35.7 & 1.9 & 37.7 & 3.6 \\
\hline Food crops & 5.8 & 9.4 & 9.5 & 1.5 & 9.1 & 2.4 & 10.2 & 2.5 \\
\hline Estate crops & 4.4 & 11.7 & 10.7 & 3.6 & 7.3 & -0.8 & 16.5 & 4.5 \\
\hline Livestock & 1.0 & 1.4 & 1.5 & 2.7 & 1.2 & 2.3 & 1.9 & 2.7 \\
\hline Forestry & 6.3 & 2.0 & 2.3 & -16.3 & 1.7 & 3.4 & 3.2 & 3.8 \\
\hline Fisheries & 8.3 & 11.7 & 12.5 & 1.8 & 16.3 & 2.7 & 6.0 & 2.7 \\
\hline Mining & 6.5 & 2.7 & 2.3 & -12.3 & 0.9 & 3.3 & 4.6 & 1.4 \\
\hline Oil \& gas & 0.5 & 0.3 & 0.3 & -7.8 & 0.5 & 2.2 & n.a & n.a \\
\hline Mining & 4.5 & 1.9 & 1.5 & -11.4 & n.a & n.a & 4.1 & 1.0 \\
\hline Quarrying & 1.5 & 0.5 & 0.5 & -18.2 & 0.5 & 4.7 & 0.5 & 6.3 \\
\hline Manufacturing & 17.5 & 9.2 & 8.1 & -9.0 & 4.6 & 1.9 & 14.1 & 3.4 \\
\hline Electricity \& water & 0.7 & 0.6 & 0.7 & -0.6 & 0.7 & -0.2 & 0.6 & 12.7 \\
\hline Electricity & 0.6 & 0.5 & 0.6 & -2.5 & 0.7 & 0.2 & 0.3 & 8.1 \\
\hline Clean water & 0.1 & 0.1 & 0.1 & 6.0 & 0.1 & -3.2 & 0.3 & 19.1 \\
\hline Construction & 7.8 & 1.4 & 1.5 & -26.0 & 1.2 & 5.5 & 1.9 & 2.6 \\
\hline $\begin{array}{l}\text { Trade, hotels \& } \\
\text { restaurants }\end{array}$ & 19.2 & 23.5 & 24.3 & 0.0 & 25.4 & 4.9 & 22.4 & 4.3 \\
\hline Trade & 18.6 & 22.7 & 23.4 & -0.2 & 24.3 & 4.9 & 22.0 & 4.2 \\
\hline $\begin{array}{l}\text { Hotels \& } \\
\text { restaurants }\end{array}$ & 0.7 & 0.8 & 0.9 & 3.0 & 1.1 & 5.5 & 0.4 & 7.3 \\
\hline $\begin{array}{l}\text { Transport \& } \\
\text { communications }\end{array}$ & 6.0 & 7.2 & 8.4 & 3.0 & 8.7 & 11.0 & 7.8 & 3.9 \\
\hline Transport & 4.8 & 6.1 & 7.0 & 4.7 & 8.0 & 11.2 & 5.3 & 3.5 \\
\hline Communications & 1.2 & 1.0 & 1.4 & -4.4 & 0.7 & 7.6 & 2.5 & 5.2 \\
\hline $\begin{array}{l}\text { Financial, rental \& } \\
\text { corporate services }\end{array}$ & 5.9 & 4.5 & 4.5 & -1.9 & 5.3 & 5.2 & 3.2 & 4.7 \\
\hline Banking & 1.6 & 1.0 & 1.1 & -2.6 & 1.4 & 5.6 & 0.5 & 5.0 \\
\hline $\begin{array}{l}\text { Non-bank financial } \\
\text { institutions }\end{array}$ & 0.5 & 0.6 & 0.7 & 2.9 & 0.9 & 6.7 & 0.4 & 16.2 \\
\hline Rental services & 3.6 & 2.8 & 2.7 & -2.6 & 2.9 & 4.7 & 2.2 & 3.0 \\
\hline Corporate services & 0.1 & 0.1 & 0.0 & 1.2 & 0.0 & 5.7 & 0.1 & 1.5 \\
\hline Other services & 10.7 & 14.9 & 13.8 & 2.8 & 17.5 & 3.3 & 7.6 & 3.1 \\
\hline Government & 9.4 & 12.9 & 11.9 & 2.7 & 15.6 & 3.3 & 5.6 & 2.9 \\
\hline Private & 1.3 & 2.0 & 1.9 & 3.3 & 1.9 & 3.2 & 2.0 & 3.6 \\
\hline Total & 100.0 & 100.0 & 100.0 & -2.7 & 100.0 & 3.9 & 100.0 & 3.7 \\
\hline
\end{tabular}

a Sectoral composition is in current prices; growth rates are in constant 1993 prices.

b New Maluku and North Maluku combined.

Source: BPS (various years).

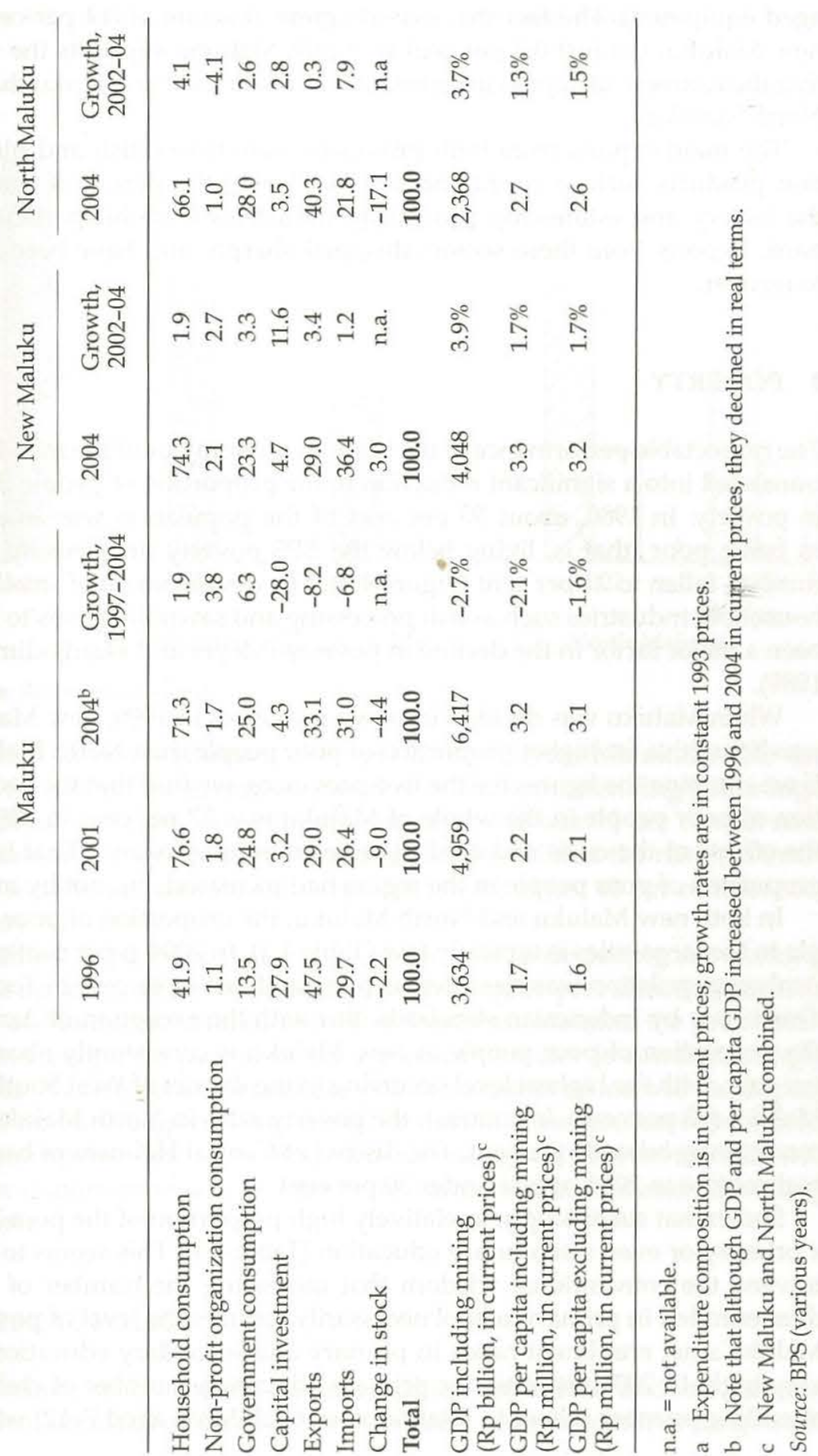


aged equipment. The fact that exports grew at a rate of 3.4 per cent in new Maluku, but just 0.3 per cent in North Maluku, supports the view that the recovery of capital investment was faster in new Maluku than in North Maluku.

The main exports from both provinces were frozen fish and plantation products such as copra and cloves. During the period of conflict, the fishery and estate-crop processing industries were hit particularly hard. Exports from these sectors dropped sharply and have been slow to recover.

\section{POVERTY}

The respectable performance of the Maluku economy until the mid-1990s translated into a significant reduction in the proportion of people living in poverty. In 1980, about 50 per cent of the population was assessed as being poor (that is, living below the BPS poverty line) but by 1996 this had fallen to 21 per cent (Figure 4.3). The development of small and household industries such as fish processing and sawmills seems to have been a major factor in the decline in poverty (Meyer and Hardjodimedjo 1989).

When Maluku was divided into two provinces in 1999, new Maluku was left with a far higher proportion of poor people than North Maluku. If we combine the figures for the two provinces, we find that the proportion of poor people in the whole of Maluku was 27 per cent in 2002, as the effects of the crisis and conflict were beginning to ease. That is, the proportion of poor people in the region had increased, but not by much.

In both new Maluku and North Maluku, the proportion of poor people in the large cities is typically low (Table 4.3). In 2004, 6 per cent of the Ambon population was classified as poor, and just 4 per cent in Ternate. This is low by Indonesian standards. But with the exception of Ambon the proportion of poor people in new Maluku is consistently above 30 per cent, with the highest level occurring in the district of West Southeast Maluku (43 per cent). In contrast, the poverty rates in North Maluku are consistently below 30 per cent. The district of Central Halmahera had the highest rate in 2004, at just under 30 per cent.

Somewhat surprisingly, a relatively high proportion of the poor have a primary or even a secondary education (Table 4.3). This seems to contravene the conventional wisdom that increasing the number of children enrolled in primary school necessarily reduces the level of poverty. Maluku's net enrolment ratios in primary and secondary education are very high. In 2004, the ratio for primary education (number of children attending primary school to total number of children aged 7-12) was 97
Figure 4.3 Maluku: Poor People as a Share of the Total Population, 1980-2004 (\%)

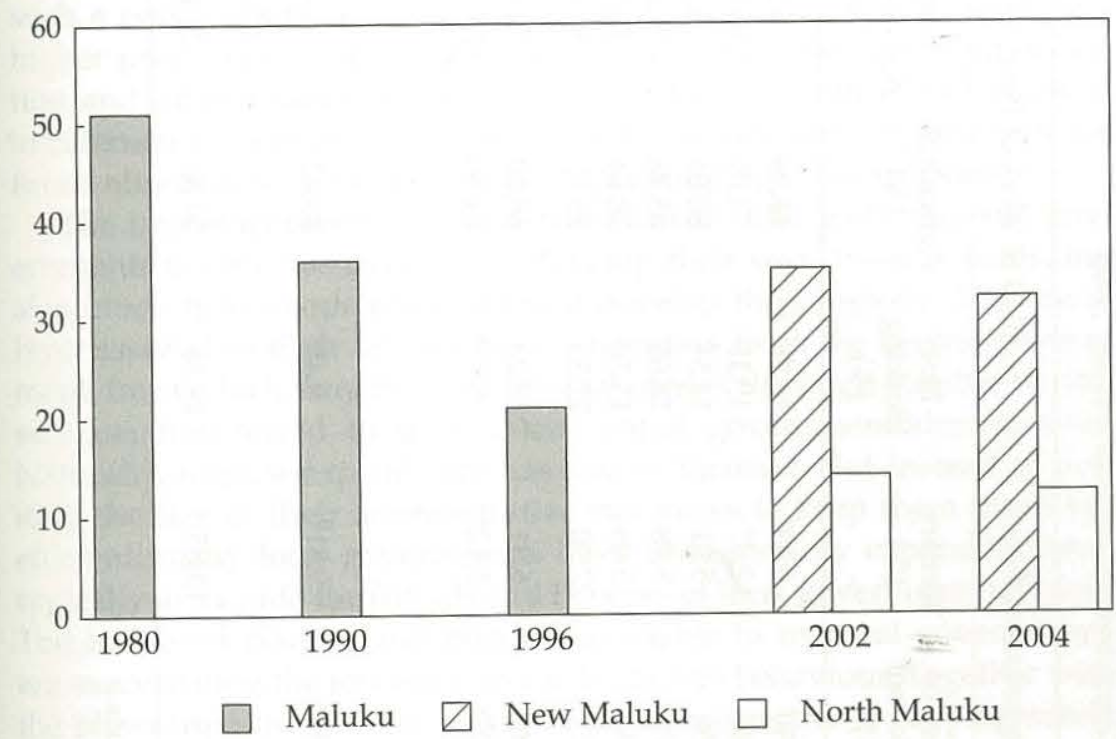

Source: BPS (various years).

per cent in new Maluku and 98 per cent in North Maluku, while the ratio for secondary education (number of children attending junior high school to total number of children aged 13-15) was 92 per cent in new Maluku and 88 per cent in North Maluku. Recall that the national averages were 93 per cent for primary education and just 60 per cent for secondary education.

Table 4.3 indicates that a large majority of poor people are working in the agricultural sector. In regions with a higher prevalence of poverty, such as Southeast Maluku and West Southeast Maluku, the proportion of poor people employed in the agricultural sector is correspondingly higher. This suggests the need for policies to assist farmers to participate in the non-farming economy, namely rural industries and services. Given the anticipated low rates of growth in the agricultural sector, this will be an important means of improving farmers' incomes and alleviating poverty.

\section{FISCAL POLICY}

In a region with challenging geographical conditions such as Maluku, prudent fiscal policy is critical. In particular, government spending needs 
to be directed at developing the basic infrastructure and human capital needed to attract private investment. The main obstacles to developing such a policy are two-fold. First, regional governments are spending a higher proportion of their budgets on civil servant salaries, administration and other routine expenditures, and less on human and physical infrastructure development. And second, a significant proportion of the funds allocated to development is evaporating due to corruption.

The implementation of decentralization in 2001 gave regional governments far greater freedom to develop their own fiscal policies, but also much heavier responsibilities to develop their regions. They have been assisted in their task by higher transfers from the central government, from which they must pay the salaries of the huge number of civil servants transferred to them from central government departments. Naturally, routine expenditure has had to increase. But instead of limiting the size of their administrative structures to keep them small but efficient, many local governments have unnecessarily expanded them, typically to include the friends and families of local government officials. The increased powers and budgets available to regional governments are exacerbating the tendency towards corrupt behaviour. Together with the blowout in the routine portion of the budget, this is sapping sorely needed funds from the development budget.?

Table 4.4 compares government revenue in Maluku in 1999/2000 (the financial year preceding decentralization) with that in 2001 and 2002 (the two years after decentralization was implemented). It can be seen that the income of new Maluku and North Maluku combined tripled between 1999/2000 and 2001. Most of the new revenue came from an expansion of the program of block grants from the central government, channelled through the General Purpose Fund (DAU).

In 2002, the DAU of new Maluku increased again by almost 90 per cent, while that of North Maluku went up by only 40 per cent. The difference is attributable to the change in formula for calculating the DAU, to place a higher weight on poverty and other indicators of development needs. Own-source revenue increased sharply in both new Maluku and North Maluku as their governments sought to impose new taxes. Both provinces need to be careful: if they continue to add to the taxation burden on business, business activity will decline and their own revenues will suffer. It is also important to note that whereas conflict-ridden provinces such as Aceh and Papua benefited from significant increases in targeted grants under the Specific Purpose Fund (DAK), Maluku did not. That is, despite the destruction delivered on the local economy by the

7 Similar problems are identified in the chapters on Papua in this book and in Resosudarmo and Kuncoro (2006). 
Table 4.4 Maluku: Government Budget, 1999/2000, 2001 and 2002 (Rp billion)

\begin{tabular}{|c|c|c|c|c|c|}
\hline & \multirow{2}{*}{$\begin{array}{c}\text { Maluku } \\
1999 / \\
2000\end{array}$} & \multicolumn{2}{|c|}{ New Maluku } & \multicolumn{2}{|c|}{ North Maluku } \\
\hline & & 2001 & 2002 & 2001 & 2002 \\
\hline TOTAL INCOME & 435.1 & 645.9 & $1,325.1$ & 664.0 & 934.7 \\
\hline Transfer from previous year & 6.0 & 30.0 & 180.6 & 16.1 & 75.7 \\
\hline Own revenue & 15.6 & 13.8 & 43.1 & 16.1 & 30.1 \\
\hline Regional tax & 6.8 & 1.9 & 16.4 & 5.4 & 12.0 \\
\hline Levies \& other income & 8.8 & 11.9 & 26.7 & 10.7 & 18.1 \\
\hline Transfer from the centre & 405.4 & 566.8 & $1,081.0$ & 568.7 & 799.2 \\
\hline Tax revenue sharing & 41.7 & 30.7 & 61.5 & 33.7 & 47.4 \\
\hline Non-tax revenue sharing & 12.5 & 3.1 & 17.8 & 35.8 & 69.5 \\
\hline SDO/DAU ${ }^{\mathrm{a}}$ & 182.9 & 528.7 & 992.4 & 476.7 & 668.6 \\
\hline Inpres/DAK ${ }^{\mathrm{a}}$ & 168.3 & 4.3 & 9.3 & 22.5 & 13.8 \\
\hline Other & 8.1 & 35.3 & 20.4 & 63.1 & 29.7 \\
\hline TOTAL EXPENDITURE & 407.3 & 587.7 & $1,147.4$ & 585.5 & 835.0 \\
\hline Routine expenditure & 232.5 & 496.7 & 820.6 & 350.7 & 517.7 \\
\hline Development expenditure & 174.8 & 91.0 & 326.8 & 234.8 & 317.3 \\
\hline Industry & 0.2 & 0.8 & 4.4 & 0.7 & 2.7 \\
\hline Agriculture & 4.8 & 4.5 & 31.7 & 12.5 & 35.5 \\
\hline Irrigation & 0.3 & 2.2 & 3.8 & 0.2 & 1.2 \\
\hline Trade & 5.6 & 6.0 & 8.8 & 6.3 & 10.6 \\
\hline Mining & 0.3 & 0.5 & 4.3 & 1.1 & 4.9 \\
\hline Telecommunications & 0.5 & 0.6 & 2.4 & 0.6 & 2.1 \\
\hline Transport & 43.5 & 19.1 & 90.3 & 40.2 & 46.9 \\
\hline Regional development & 42.7 & 5.1 & 29.1 & 16.2 & 18.0 \\
\hline Environment & 1.2 & 1.3 & 12.1 & 2.5 & 16.0 \\
\hline Education & 25.1 & 16.8 & 34.3 & 27.7 & 40.9 \\
\hline Health & 13.2 & 7.9 & 16.5 & 33.6 & 28.2 \\
\hline Housing & 14.2 & 15.5 & 33.0 & 49.0 & 46.6 \\
\hline Science & 11.3 & 1.0 & 4.3 & 1.9 & 2.2 \\
\hline Judicative apparatus & 0.1 & 0.5 & 1.6 & 0.5 & 1.3 \\
\hline Government apparatus & 9.8 & 6.6 & 40.8 & 32.6 & 45.3 \\
\hline Security & 0.7 & 0.8 & 2.3 & 2.3 & 6.2 \\
\hline Other & 1.3 & 1.8 & 7.1 & 6.9 & $8.7^{3}$ \\
\hline
\end{tabular}

a Figures for 1999/2000 are Autonomous Regional Subsidy (SDO) or Presidential Instruction (Inpres) grants; figures for 2001 and 2002 are General Purpose Fund (DAU) or Specific Purpose Fund (DAK) grants.

Source: Department of Finance (http://www.sikd.djapk.go.id/). conflict, it appears that Maluku did not receive any special compensatory treatment from the central government.

Both new Maluku and North Maluku spent a significant proportion of their income on routine expenditure, that is, on civil servant salaries and local government administration (Table 4.4). Expenditure on government administration was of course inflated by the division of Maluku into two provinces (ICG 2007).

New Maluku was the region most affected by the unrest, and consequently the one most in need of higher than usual development allocations. Nevertheless, it allocated only 15 per cent of its total expenditure to development in 2001, rising to 28 per cent in 2002. This was far less than North Maluku, which allocated 40 per cent to development in 2001 and 38 per cent in 2002. The higher spending on development in North Maluku is likely to induce a faster recovery there than in new Maluku.

The breakdown shown in Table 4.4 indicates that both provinces spent similar proportions on the various components of the development budget. The large expenditures on government apparatus (mainly buildings) provide another indication of the expansion in the size of the civil services and administrative activities of both provinces.

Both new Maluku and North Maluku need to reel back their routine expenditures and spend more on development. Developing and maintaining infrastructure such as roads, ports, markets and utilities should be the main priority. At the same time, when implementing infrastructure projects, both provincial governments need to ensure that administrative costs and losses due to corruption are minimized.

\section{CONCLUDING REMARKS}

Maluku continues to be counted among Indonesia's backward regions. However, this does not mean that there has been no progress. In fact, from the mid-1970s until the mid-1990s, Maluku progressed quite well on several fronts: GDP grew at an average rate of 7.5-8 per cent per annum; the proportion of poor people declined from 50 per cent in 1980 to 20 per cent in 1996; and at the end of the 1990s Maluku ranked fifth among Indonesia's 26 provinces on the HDI.

The main engines of growth from the mid-1970s through mid-1990s were the industrial and service sectors. During that period Maluku made steady progress in shifting its economy from agriculture to industry and services - a pattern typical of a successful region (Hill 1989). Nevertheless, in 1996 Maluku was still categorized as a backward region.

In the late 1990s the direction of progress suddenly reversed as Maluku experienced its share of the chaos created by the Asian economic crisis, 
then succumbed to socio-political unrest. When the conflict of 1999-2003 finally receded, Maluku's economy was in a state of near-collapse: the industrial sector had been destroyed and much of the region's basic infrastructure was defunct. In 1999, Maluku was split into two provinces: 'new' Maluku and North Maluku.

There is reason to hope that new Maluku and North Maluku will get back on track. First, government transfers to the region have increased significantly. These funds need to be spent wisely and efficiently, particularly on the infrastructure needed for the economy to function well, such as transport, markets and utilities. Second, conflict resolution has been progressing (see Chapter 12). And third, Maluku has relatively well-developed human capital, better than in many other regions in Indonesia.

But Maluku also faces several challenges. First, despite being a postconflict region like Papua and Aceh, Maluku has not received extra assistance from the national government in the form of increased central government transfers. Second, both Maluku governments still spend a large proportion of their budgets on salaries and administration rather than development. Third, repairing and replacing damaged infrastructure will take time, and restoring investor confidence will take even longer. Fourth, the creation of additional districts has been costly in terms of absorbing government funds that could have been used to provide badly needed infrastructure, and has disrupted existing development programs. Hence, it will be some time yet before Maluku returns to its former growth trajectory.

\section{ACKNOWLEDGMENTS}

The author would like to thank Mukhtar A. Adam of Khairun University, Ternate, and Craig Thorburn of Monash University, Melbourne, for their useful suggestions and comments, and Ditya A. Nurdianto and Yogi Vidyattama for their research assistance. Any mistakes remain the author's responsibility.

\section{REFERENCES}

BPS (Badan Pusat Statistik) (various years), Statistik Indonesia [Statistics of Indonesia], Jakarta.

BPS (Badan Pusat Statistik) (1981), Penduduk Indonesia: Hasil Sensus Penduduk Tahun 1980 [Population of Indonesia: Results of the 1980 Population Census], Jakarta.
BPS (Badan Pusat Statistik) (1991), Penduduk Indonesia: Hasil Sensus Penduduk Tahun 1990 [Population of Indonesia: Results of the 1990 Population Census], Jakarta.

BPS (Badan Pusat Statistik) (1996), Laporan Indeks Pembangunan Manusia 1996 [Report on the 1996 Human Development Index], Jakarta.

BPS (Badan Pusat Statistik) (2001), Penduduk Indonesia: Hasil Sensus Penduduk Tahun 2000 [Population of Indonesia: Results of the 2000 Population Census], Jakarta.

BPS (Badan Pusat Statistik) (2003), Keadaan Angkatan Kerja Indonesia 2002 [The Labour Force Situation in Indonesia, 2002], Jakarta.

BPS (Badan Pusat Statistik) (2005), Data dan Informasi Kemiskinan Tahun 2004 [Data and Information on Poverty, 2004], Jakarta.

BPS (Badan Pusat Statistik) (2006a), Penduduk Indonesia: Hasil Survei Penduduk Antara Sensus Tahun 2005 [Population of Indonesia: Results of the 2005 Intercensal Survey], Jakarta.

BPS (Badan Pusat Statistik) (2006b), Statistik Indonesia [Statistics of Indonesia], Jakarta.

BPS, Bappenas and UNDP (Badan Pusat Statistik, Badan Perencanaan Pembangunan Nasional and United Nations Development Programme) (2001), Indonesia Human Development Report 2001. Towards a New Consensus: Democracy and Human Development in Indonesia, Jakarta.

BPS, Bappenas and UNDP (Badan Pusat Statistik, Badan Perencanaan Pembangunan Nasional and United Nations Development Programme) (2004), Indonesia Human Development Report 2004. The Economics of Democracy: Financing Human Development in Indonesia, Jakarta.

Brown, G., C. Wilson and S. Hadi (2003), Overcoming Violent Conflict: Peace and Development Analysis in Maluku and North Maluku, CPRU-UNDP, LIPI and Bappenas, Jakarta.

Duncan, C.R. (2005a), 'The Other Maluku: Chronologies of Conflict in North Maluku, Eastern Indonesia', Indonesia, 80: 53-80.

Duncan, C.R. (2005b), 'Unwelcome Guests: Relations between Internally Displaced Persons and Their Hosts in North Sulawesi, Indonesia', Journal of Refugee Studies, 18(1): 25-46.

Hill, H. (ed.) (1989), Unity and Diversity: Regional Economic Development in Indonesia since 1970, Oxford University Press, Oxford and Singapore.

ICG (International Crisis Group) (2007), 'Indonesia: Decentralisation and Local Power Struggles in Maluku', Asia Briefing No. 64, Brussels.

Meyer, P.A. and M. Hardjodimedjo (1989), 'Maluku: The Modernization of the Spice Islands', in H. Hill (ed.), Unity and Diversity: Regional Economic Development in Indonesia since 1970, Oxford University Press, Oxford and Singapore, pp. 548-65.

Monk, K.A., Y. de Fretes and G. Reksodiharjo-Lilley (1997), The Ecology of Nusa Tenggara and Maluku, Periplus Editions, Singapore.

Pariela, T.D. (2007), 'Political Process, Public Policy, and Peace Building Process: Case of Ambon City, Maluku', in K. Matsui (ed.), Regional Development Policy and Direct Local-Head Election in Democratizing East Indonesia, ASEDP No. 76 , IDE-JETRO, Chiba, pp. 101-23.

Resosudarmo, B.P. and A. Kuncoro (2006), 'The Political Economy of Indonesian Economic Reform: 1983-2000', Oxford Development Studies, 34(3): 341-55.

van Klinken, G. (2001), 'The Maluku Wars', Indonesia, 71: 1-26. 